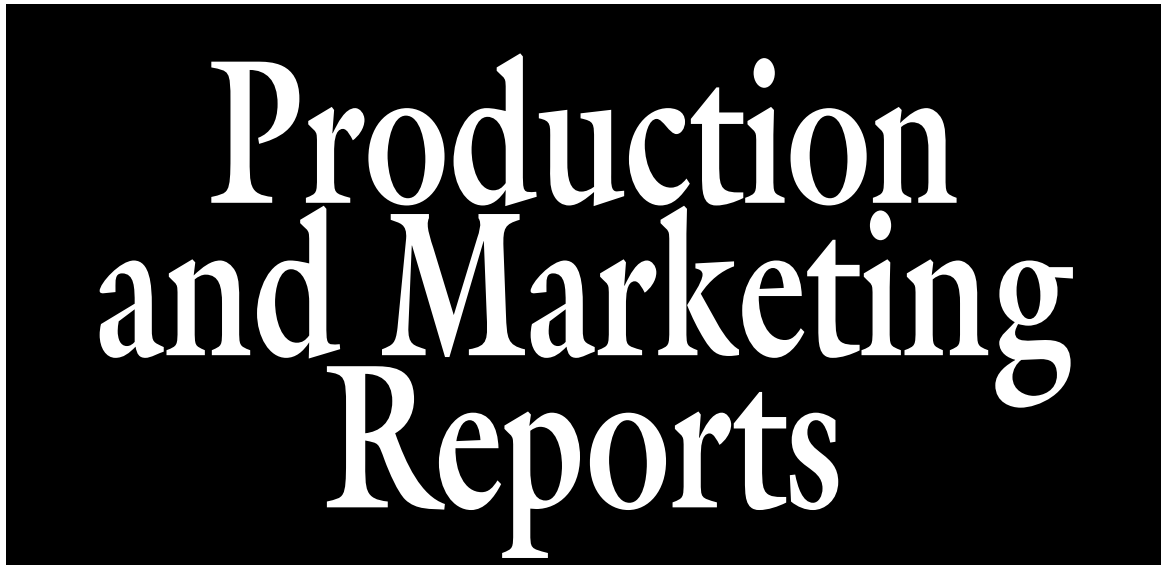

\section{Factors Influencing Consumers' Selection of a Landscaping Service Provider}

\author{
Michael S. McCoy ${ }^{1}$, Kathleen M. Kelley ${ }^{2}$, and Dan T. Stearns ${ }^{3,4}$
}

ADDITIONAL INDEX WORDs. survey mail questionnaire, statistics, consumer research, landscape contracting

SuMMARY. The Associated Landscape Contractors of America reported in 2004 that the lawn and landscape industry experienced considerable growth during the last 10 years: an increase of $31 \%$ from 2002 to 2003 , and 126\% from 1998 to 2003 . An understanding by landscaping professionals of what factors influence consumers' evaluation and selection process when purchasing landscaping services is instrumental in formulating business and marketing plans that will more effectively target new customers, increase the customer base, and ultimately increase profits. To determine these factors, a questionnaire was developed and mailed to 5000 randomly selected households in the metro-Philadelphia area. Recipients were asked to consider factors deemed relevant to the selection and purchase of a landscaping service provider and rank them in order of importance. Questions pertaining to both the landscape industry, such as types of services purchased or how much was spent on these services, and the participants' demographic status were included. A total of 504 completed surveys were received, representing a $10 \%$ response rate. Results indicated that the "quality of work" factor was most important, followed by "cost," and "types of services offered" when analyzed by both the frequency as well as by an average mean ranking of factors. Further analysis of results showed little or no influence on the ordering of factors by independent variables, such as types of service purchased, how much was spent on the service(s), household income, or education levels of the participants.

$\mathrm{R}$ esults from a 2004 survey involving a nationwide sample of 2004 U.S. adults, age 18 years and older, indicated that consumers spent $\$ 28.9$ billion on lawn and landscaping-related services in 2002 , and $\$ 37.9$ billion in 2003 ,

\footnotetext{
Department of Horticulture, The Pennsylvania State University, University Park, PA 16802

We greatly appreciate the assistance given to us by Dr. Edgar Yoder, Professor of Agricultural Extension, The Pennsylvania State University.

${ }^{1}$ Graduate Student.

${ }^{2}$ Assistant Professor.

${ }^{3}$ Professor

${ }^{4}$ Corresponding author. E-mail: dts3@psu.edu.
}

representing a $31 \%$ growth rate from 2002 to 2003 (Associated Landscape Contractors of America, 2004). The survey was commissioned by the Associated Landscape Contractors of America (ALCA) and conducted by Harris Interactive (Rochester, NY) using the Harris Poll online database of several million people who agreed to participate in online research. Participants were asked about their likelihood to purchase landscaping services for 2004 to identify critical trends and buying practices in the lawn and landscaping industry.

Bruce Butterfield, Marketing Research Director for the National
Gardening Assn. (South Burlington, VT), added further support to this industry growth, indicating that consumers' purchases of landscape installation and construction services were $\$ 14.3$ billion in 2003 , a $28 \%$ increase over 2002 , and a $126 \%$ over 1998 . This trend represents the fastest growing segment in the professional lawn, landscaping, and tree services industry (B. Butterfield, unpublished data).

In addition to capturing consumer responses regarding their intention to purchase lawn and landscaping services, the ALCA survey quantified the resources used by consumers when they searched for landscaping services, as well as what criteria they use when they finally selected the landscaping service provider to perform their requested services (Associated Landscape Contractors of America, 2004). More than half (55\%) the survey participants indicated that "referrals from friends and/or family" was the most important informational resource, whereas $22 \%$ indicated that both the "telephone directory" and other forms of "advertising" aside from the Internet, direct mail, or flier were considered (Associated Landscape Contractors of America, 2004). Although "referrals from friends and/or family" represented the primary resource used during the search for a landscaping service provider, it had less of an effect than "cost," which was ranked as the top influencing factor $(83 \%)$, when consumers actually selected a landscaping service provider (Associated Landscape Contractors of America, 2004).

Besides the ALCA survey there is little peer-reviewed research available in the lawn and landscaping industry to assist managers with understanding 1) consumer preferences for desired services and 2) factors that influence consumer's decision to choose a landscaping service provider. The review of the literature by Barton et al. (1998) revealed that little scholarly work had been directed toward understanding customer preferences in the decision to purchase within the nursery and landscape industries. Additionally, Behe et al. (2005) found little consumer research available to help landscape installation and construction businesses develop service marketing strategies. 
Service marketing research in other industries indicated that when consumers sought services from licensed or certified professionals, such as doctors and lawyers, consumers relied primarily on sources of information (e.g., "recommendations from friends or family") to make their selection decision (Ettenson and Turner, 1997). In contrast, when choosing services from nonprofessionals, such as dry cleaners and hair stylists, the factor's order of importance differed depending upon which nonprofessional service was sought (Ettenson and Turner, 1997). Ettenson and Turner's (1997) conclusion revealed that a consumer's perspective of the nonprofessional service category is not treated as a homogeneous group when it comes to evaluating them.

Judy Guido, principal of Guido and Associates (Moorpark, CA), a national consulting firm for the green industry, has found through her own research that consumers perceive the level of service within the lawn and landscaping industry, specifically with how companies market themselves to consumers, to be indistinguishable. She found that consumers use criteria such as 1) how easy it is to find out about a company and 2) how quickly contact can be made between the consumer and a company to be of utmost importance (Guido, 2005). To improve their position, landscape professionals should develop a better understanding of what drives a consumer's decision when using their services, but only $25 \%$ of landscaping construction companies perform these functions (Guido, 2004). Guido also stressed the importance, albeit to a lesser extent of a landscaping professional's scope of experience, skill sets, guarantees, licensure, types of services offered, proximity, and level of trust as influencing factors in the decision process (J. Guido, pers. comm.).

This consumer research study was conducted to determine the factors consumers consider in the decision-making process (e.g., cost, types of services offered, and recommendations from friends and family), the order of importance of these factors, and variables that contribute to the ordering of these factors.

For survey construction, asking consumers directly about what factors influence their decision process is considered to be "self-explicated" and is a poor indicator of the actual purchase (Ettenson and Turner, 1997). Therefore, relying on preexisting criteria established by industry professionals became the basis for formulating the response choices for the question of what influenced consumer's selection decision. "Environmental consciousness" was not mentioned as a factor in previous studies. However, "environmental soundness," at least with products, "is increasingly becoming one of the core purchasing criteria that a majority of consumers use to make purchases" (Beckwith, 1996). As a result "environmental consciousness" was included as a response choice in this study.

\section{Methods and materials}

A traditional postal mailing to randomly selected single-family residences in the metro-Philadelphia area was used for survey distribution. Regions represented in the metroPhiladelphia area include southeastern Pennsylvania, southern New Jersey, northern Delaware, and Cecil County, MD. Single-family residences represent $89 \%$ of homeownership in the metro-Philadelphia area, and $80 \%$ within U.S. metropolitan areas (U.S. Census Bureau, 2005). Furthermore, the metro-Philadelphia area is ranked fifth nationally in effective buying income, a measurement of disposable income, and fourth nationally in total households (Ligos, 2001).

A modified Dillman's tailored design method was used to guide survey construction, estimate projected response rate, and formulate the process for administering mailings (Dillman, 2000). A response rate of $10 \%$ to $50 \%$ could be expected if all five steps of Dillman's approach were followed (Dillman, 2000). Given the wide range of potential response rates and budgetary limitations, only the initial mailing and follow-up reminder postcards from Dillman's five-step approach were used. As a result, we concluded that an $8 \%$ response rate would be acceptable for this study.

The survey consisted of 31 questions. The first 17 questions were related to landscaping services, followed by a series of demographic questions. The first question asked consumers if they had previously purchased landscaping services. Consumers who responded that they had not purchased any landscaping services were directed to the demographic questions because the remainder of the survey did not pertain to them.

Response choices to the question of what influenced the consumer's selection decision were determined from review of the literature, and a comparison was made against factors presented in the ALCA survey. As a result, the final listing of response choices included "quality of work," "cost," "types of services offered," "recommendations from friends and/ or family," "schedule for completing the project," "environmental consciousness," "professionals being in good standing with the local Better Business Association" (BBA), and "professional meeting state licensing requirements." Customer service was omitted primarily because of its highly subjective nature and varying degrees of definition. Proximity to home was omitted because of the low response in the ALCA survey, and the fact that the landscape contractor is responsible for traveling to the homeowner's property.

The survey was pretested for question relevancy, understanding, and overall construction using 11 participants from The Pennsylvania State University horticulture faculty, industry professionals, and consumers. None of the 11 participants were included in the final sample.

For statistical analysis, the dependent variables include the eight response choices to the question: What influenced your selection decision? (e.g., cost, quality of work, types of services offered). Responses were recorded using a 1- to 8-point Likerttype scale ranging from 1 point being the most influential to 8 points being the least influential. Independent variables included industry-related characteristics (e.g., types of services offered, how much was spent on services performed) and demographic characteristics.

Names and addresses for 5000 randomly selected households were obtained from Survey Sampling International (Fairfield, CT). The initial mailing, sent on 2 Dec. 2005, included a multipurpose cover letter that described the nature of the research, invited the recipient to participate voluntarily, and included a voluntary consent statement required by the Office of Research Protection at The Pennsylvania State University. 
A self-addressed, postage-paid, return envelope also was provided. Followup/reminder postcards were mailed $7 \mathrm{~d}$ later on 9 Dec. 2005. Completed surveys were received by the researchers between 15 Dec. 2005 and 17 Mar. 2006.

The protocol and survey instrument were approved by the internal review board through the Office of Research Protection at The Pennsylvania State University. All data were coded and entered into SPSS (version 12; SPSS, Chicago) for analysis using descriptive and inferential statistics.

\section{Results and discussion}

General demographics. Fivehundred four usable questionnaires were received, resulting in a $10 \%$ response rate. A majority of respondents to the survey were male $(63.3 \%)$ and of white/Anglo decent (88.2\%). Additionally, $96.2 \%$ indicated owning their own home, and $57.3 \%$ indicated living in their home for more than 10 years. A large percentage of respondents indicated earning at least an associate's degree (70.5\%), and $72.7 \%$ were currently employed. Forty-one percent reported earning more than $\$ 100,000$ annually, and $37.7 \%$ indicated the market value of their home at more than $\$ 350,000$.

D E M O G R A P H I C S A N D PSYCHOGRAPHICS OF LANDSCAPE SERVICE PURCHASERS. Of the 504 responses, 315 participants $(62.5 \%)$ indicated that they had purchased some form of landscaping services: maintenance or installation. When analyzing demographic responses between participants who had purchased only maintenance services versus participants who purchased only installation services, only four characteristics were statistically different: level of education, occupation, market value of home, and household income (Table $\mathrm{l}$ ). The $\mathrm{n}$ values, where $n$ is equal to the number of valid responses by participants to each demographic and psychographic question, fluctuated depending on how many participants responded to each individual question. Results suggest that these four characteristics had some influence on the types of services purchased by consumers in the metro-Philadelphia area. Consumers who were currently employed, earned at least an associate's degree, whose market value of their home was

Table 1. Demographic responses by purchasers of either maintenance services or installation services to questions in a mail survey sent to single-family households in the metro-Philadelphia area on 2 Dec. 2005.

\begin{tabular}{|c|c|c|c|c|}
\hline \multirow[b]{2}{*}{ Demographics } & \multicolumn{2}{|c|}{ Installation services $^{\mathrm{z}}$} & \multicolumn{2}{|c|}{ Maintenance services } \\
\hline & $\mathbf{n}$ & Valid \% & $\mathbf{n}$ & Valid \% \\
\hline \multicolumn{5}{|l|}{ Gender } \\
\hline Male & 111 & $62.7 \mathrm{NS}$ & 84 & 61.8 \\
\hline Female & 66 & 37.3 & 52 & 38.2 \\
\hline \multicolumn{5}{|l|}{ Education } \\
\hline Less than college degree & 39 & $36.4^{*}$ & 40 & 51.3 \\
\hline Associate degree or higher & 68 & 63.6 & 38 & 48.7 \\
\hline \multicolumn{5}{|l|}{ Occupation } \\
\hline Retired/other & 35 & $21.2^{*}$ & 41 & 31.5 \\
\hline Employed & 130 & 78.8 & 89 & 68.5 \\
\hline \multicolumn{5}{|l|}{ Dual income } \\
\hline Yes & 88 & $50.3 \mathrm{NS}$ & 63 & 47.7 \\
\hline No & 87 & 49.7 & 69 & 52.3 \\
\hline \multicolumn{5}{|l|}{ Market value of home } \\
\hline$\leq \$ 350,000$ & 70 & $39.3^{*}$ & 86 & 63.2 \\
\hline$>\$ 350,000$ & 108 & 60.7 & 50 & 36.8 \\
\hline \multicolumn{5}{|l|}{ Primary decision maker } \\
\hline Yes & 138 & 80.7 NS & 105 & 82.0 \\
\hline No & 33 & 19.3 & 23 & 18.0 \\
\hline \multicolumn{5}{|l|}{ Household income } \\
\hline$<\$ 100,000$ & 57 & $39.6^{*}$ & 79 & 67.5 \\
\hline$\geq \$ 100,000$ & 87 & 60.4 & 38 & 32.5 \\
\hline \multicolumn{5}{|l|}{ Ethnicity } \\
\hline White & 159 & $89.3 \mathrm{NS}$ & 115 & 84.6 \\
\hline All other & 19 & 10.7 & 21 & 15.4 \\
\hline \multicolumn{5}{|l|}{ Length of time at residence } \\
\hline $0-10$ years & 84 & $48.0 \mathrm{NS}$ & 51 & 38.1 \\
\hline$>10$ years & 91 & 52.0 & 83 & 61.9 \\
\hline \multicolumn{5}{|l|}{ Type of home } \\
\hline Single family & 155 & $87.1 \mathrm{NS}$ & 122 & 89.7 \\
\hline Other & 23 & 12.9 & 14 & 10.3 \\
\hline \multicolumn{5}{|l|}{ Own home } \\
\hline Yes & 173 & $98.9 \mathrm{NS}$ & 132 & 98.5 \\
\hline No & 2 & 1.1 & 2 & 1.5 \\
\hline
\end{tabular}

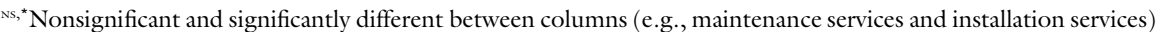
within a demographic variable (e.g., household income) per survey question at $P \leq 0.05$.

${ }^{z}$ Sum of $n$ value for type of services purchased is dependent on how many participants responded to each demographic question.

$\geq \$ 350,000$, or who had a household income of $\geq \$ 100,000$ were more likely to purchase installation services alone or in combination with maintenance services.

Participants who had purchased landscaping services (either maintenance or installation) were asked to indicate what resources they used when investigating potential landscaping service providers (Table 2). Consistent with data published in the ALCA 2004 survey, results indicated that "referrals from friends and/or family" was the primary resource at $53 \%$ (55\%, ALCA survey results). Table 2 summarizes participant responses by purchasers of landscaping services, purchasers of mainte- nance services, and purchasers of installation services. Responses add to more than $100 \%$ because multiple responses were allowed.

Purchasers of installation SERVICES. To determine differences in responses, data were divided and analyzed between those who purchased installation services and those who purchased maintenance services. No differences were found between the two groupings (data analysis results not presented). Analysis of responses for those who purchased installation services appears in the following paragraphs.

Of the 315 participants who had purchased landscaping services, $178(56.5 \%)$ reported purchasing 
Table 2. Responses from participants to a mail survey sent to single-family households in the metro-Philadelphia area on 2 Dec. 2005 when asked: "How did you obtain a list of contractor names?"

\begin{tabular}{|c|c|c|c|c|c|c|}
\hline \multirow[b]{2}{*}{ Resource used } & \multicolumn{2}{|c|}{$\begin{array}{l}\text { Installation } \\
\text { services }\end{array}$} & \multicolumn{2}{|c|}{$\begin{array}{l}\text { Maintenance } \\
\text { services }\end{array}$} & \multicolumn{2}{|c|}{$\begin{array}{l}\text { Landscape } \\
\text { services }^{\mathrm{z}}\end{array}$} \\
\hline & $\mathbf{n}$ & Valid \% & $\mathbf{n}$ & Valid \% & $\mathbf{n}$ & Valid \% \\
\hline Yellow pages & 53 & 29.9 & 67 & 24.3 & 80 & 25.6 \\
\hline Internet & 5 & 2.8 & 7 & 2.5 & 8 & 2.6 \\
\hline Reputation & 67 & 37.9 & 92 & 33.3 & 100 & 31.9 \\
\hline Flyer & 23 & 13.0 & 41 & 14.9 & 42 & 13.4 \\
\hline Company logo & 5 & 2.8 & 6 & 2.2 & 8 & 2.6 \\
\hline TV or radio & 1 & 0.6 & 3 & 1.1 & 3 & 1.0 \\
\hline \multicolumn{7}{|l|}{ Referral from } \\
\hline friend or family & 93 & 52.5 & 147 & 53.3 & 166 & 53.0 \\
\hline \multicolumn{7}{|l|}{ Referral from } \\
\hline $\begin{array}{c}\text { area professional } \\
\text { Advertisements other }\end{array}$ & 25 & 14.1 & 22 & 8.0 & 25 & 8.0 \\
\hline than phone book & 23 & 13.0 & 35 & 12.7 & 39 & 12.5 \\
\hline Telephone & 2 & 1.1 & 5 & 1.8 & 5 & 1.6 \\
\hline Direct mail & 8 & 4.5 & 17 & 6.2 & 17 & 5.4 \\
\hline Other & 23 & 13.0 & 35 & 12.7 & 42 & 13.4 \\
\hline Total no. of responses & & 78 & & & & 5 \\
\hline
\end{tabular}

${ }^{\mathrm{z}}$ Landscape services include both maintenance and installation services.

Responses summarized by category (respondents who purchased landscaping services, respondents who purchased maintenance services, and respondents who purchased installation services.) Responses add to more than $100 \%$ because multiple responses were allowed.

Table 3. Responses from participants to a mail survey sent to single-family households in the metro-Philadelphia area on 2 Dec. 2005 when asked: "What influenced your selection decision ( 1 pt = most influential; 8 pt = least influential)?”

\begin{tabular}{|c|c|c|c|}
\hline \multirow[b]{2}{*}{ Factors } & \multicolumn{3}{|c|}{ Mean value rating ${ }^{\mathrm{z}}($ mean $\pm \mathrm{SE})$} \\
\hline & $\begin{array}{l}\text { Installation } \\
\text { services }\end{array}$ & $\begin{array}{l}\text { Maintenance } \\
\text { services }\end{array}$ & $\begin{array}{l}\text { Landscape } \\
\text { services }^{\mathrm{y}}\end{array}$ \\
\hline Quality of work & $1.64 \pm 0.078$ & $1.85 \pm 0.084$ & $1.83 \pm 0.077$ \\
\hline Cost & $2.62 \pm 0.121$ & $2.37 \pm 0.105$ & $2.39 \pm 0.095$ \\
\hline Types of services offered & $3.98 \pm 0.165$ & $3.73 \pm 0.145$ & $3.88 \pm 0.138$ \\
\hline $\begin{array}{l}\text { Schedule for completing } \\
\text { the project }\end{array}$ & $4.13 \pm 0.150$ & $4.35 \pm 0.132$ & $4.29 \pm 0.122$ \\
\hline $\begin{array}{l}\text { Recommendations of } \\
\text { friends and family }\end{array}$ & $4.30 \pm 0.209$ & $4.35 \pm 0.180$ & $4.35 \pm 0.169$ \\
\hline $\begin{array}{l}\text { Environmental } \\
\text { consciousness }\end{array}$ & $5.35 \pm 0.179$ & $5.07 \pm 0.156$ & $5.23 \pm 0.146$ \\
\hline $\begin{array}{l}\text { Meeting state licensing } \\
\text { Standing with Better }\end{array}$ & $6.10 \pm 0.160$ & $6.12 \pm 0.147$ & $6.11 \pm 0.134$ \\
\hline Business Association & $6.25 \pm 0.199$ & $6.13 \pm 0.177$ & $6.15 \pm 0.162$ \\
\hline Total no. of responses & 178 & 277 & 315 \\
\hline
\end{tabular}

installation services. For purchasers of installation services, $111 \quad(62.4 \%)$ reported they spent up to $\$ 5000$ annually, and an additional 20 (11.2\%) reported they spent between $\$ 5000$ and $\$ 9999$ annually on these services. Installation services purchased by these participants include plantings $(52.2 \%)$, hardscapes $(46.1 \%)$, seed/sod $(32.6 \%)$, design $(29.8 \%)$, walls $(25.3 \%)$, irrigation
(14.6\%), lighting (13.5\%), and construction of outdoor living spaces (8.4\%).

Responses about selection decision indicated "quality of work" as the factor selected the most $(50.7 \%)$ for landscaping services. Analyzing responses from participants who purchased only installation services, "quality of work" also represented the factor selected the most (58.0\%), followed by "cost" (21.9\%) and "recommendations of friends and/ or family" (17.2\%).

Because the ordering of factors was reported using a numerical ranking, the mean value ranking was used to analyze data further (Table 3 ). Based on this approach, "quality of work" was the most important factor with a mean $( \pm \mathrm{SE})$ of $1.64 \pm$ 0.078 for participants who purchased installation services. Landscape professionals "standing with local BBA" was the least important factor, with a mean $( \pm$ SE) of $6.25 \pm 0.199$. By looking at the SE of the means, it can be determined whether the mean of one factor falls into the range of another factor. Limits of each of the means are determined by taking two times the $\mathrm{SE} \pm$ the mean of each factor. Using this methodology, the factors "types of services offered," "schedule for completing the project," and "recommendation from friends and/or family" were about equally important for respondents who had purchased installation services. The same can be said for the factors "meeting state licensing requirements" and "standing with BBA." Therefore, the final ordering of factors by order of importance for respondents purchasing installation services was "quality of work," "cost," "types of services offered," "schedule for completing the project" and "recommendations from friends and/or family," "environmental consciousness," and "meeting state licensing requirements" and "standing with local BBA."

Survey responses were dissimilar to responses from the 2004 ALCA survey, in which "cost" was the most important factor, followed by "recommendation from friends and/or family" and "customer service." This survey revealed that "quality of work" was the most important factor, followed by "cost" and "types of services offered." Certainly, the definition for quality of work is somewhat nebulous and difficult to place a tangible value upon. The ALCA survey looked at an equally ambiguous factor in "customer service." However, ALCA survey participants reported "customer service" as third in importance whereas "cost" and "recommendations from friends and/or family were reported as first and second respectively. Perhaps the reason for this dissimilarity has to do with two 
Table 4. Summary of results with "quality of work" factor regressed on selected predictors to determine the strength of relationship on respondents ranking of factors that influence the selection of a landscaping service provider.

\begin{tabular}{|c|c|c|c|c|c|}
\hline Factor $^{\mathrm{z}}$ & b & $\mathrm{SE}$ & $\beta$ & $t$ & $P$ \\
\hline Constant & 1.31 & 0.20 & & & \\
\hline $\begin{array}{l}\text { Education level } \\
\text { Less than college degree versu } \\
\text { degree or higher }\end{array}$ & 0.50 & 0.21 & 0.27 & 2.45 & 0.017 \\
\hline $\begin{array}{l}\text { Market value of home } \\
\leq \$ 350,000 \text { versus }>\$ 350,000\end{array}$ & -0.18 & 0.21 & -0.09 & -0.87 & 0.389 \\
\hline $\begin{array}{l}\text { Amount spent on installation } \\
<\$ 10,000 \text { versus } \geq \$ 10,000\end{array}$ & 0.43 & 0.22 & 0.21 & 1.96 & 0.053 \\
\hline
\end{tabular}

Model summary ${ }^{\mathrm{y}}$

$\mathrm{F}=3.15 ; \mathrm{df}=3,78 ; P=0.03 ; R^{2}=0.11$

${ }^{2}$ Predictors: constant, recoded education level, recoded market value of home, recoded amount spent on installation.

${ }^{\mathrm{y}}$ Dependent variable: quality of work.

different survey populations or by the inclusion of "quality of work" as a decision factor in this survey.

To identify the independent variables that may have an influence on the mean value ordering of factors for the purchase of installation services, data were analyzed using point biserial correlations between the independent variables and the top two factors ("quality of work" and "cost"). Results from the correlations indicated that a participant's education level had a relatively low correlation value to the "quality of work" factor $(0.237)$, but was statistically significant with $P=0.032$. This indicates that consumers who hold an associate's degree or higher were more likely to purchase installation services than those holding less than some form of college degree. All other independent variables analyzed produced no significant correlations to either "quality of work" or "cost" factors.

To determine whether several independent variables combined would influence the ordering of factors, variables showing the greatest potential to have some influence were identified as education level, amount spent, and market value of home. Table 4 shows the multiple regression results of variables that influenced the rating of the "quality of work" factor. Although results are significant at $P=$ 0.03 , the degree of influence is relatively low at $11 \%\left(R^{2}=0.11\right)$, indicating that $11 \%$ of the influence on the "quality of work" factor can be attributed to the combination of these three variables. It would be difficult for landscaping service providers to place much value in these results because they indicate that $\approx 89 \%$ of the influence on "quality of work" remains unidentified.

Further analysis of these same influencing variables against the rating of the "cost" factor indicated no significance at the $P \leq 0.05$ level. Additionally, upon recoding the "amount spent" factor into new categories $-<\$ 5000$ and $\geq \$ 5000$ - the influence was even less significant.

\section{Conclusion}

"Quality of work" has an important role in the evaluation and selection process for consumers in the metro-Philadelphia area. For this reason alone, landscape contractors should value a universal definition of how they could best communicate the level of quality of work they perform. Examples could include demonstration of awards won for design and installation or examples of completed projects. Landscape contractors in the metro-Philadelphia area also need to be aware that "referrals from friends and/or family" is an important resource used by consumers seeking a landscaping service provider. Landscape contractor's understandings, therefore, of how they can influence both needed quality referrals and how to communicate their quality of work remain discussion points and potential subject matter for future studies.

Just because "quality of work" is what participants indicated as most important, it does not suggest that cost is not an important factor in their decision. For contractors in the metro-Philadelphia area who believe they perform top-quality work, perhaps the greatest potential for them to acquire new customers lies in targeting potential customers who are looking for installation services and whose demographic characteristics are similar to those outlined in Table 4: possess at least an associate's degree, with a home value more than $\$ 350,000$, and spending on landscaping installation an amount $\geq \$ 10,000$.

Lastly, the development of trust and its impact on either acquiring new business or its role in the decision process needs to be explored. It could be argued that there is an inherent level of trust transferred to a potential client from an existing or previous customer of a landscaping service provider. "Recommendations from friends and/or family" ranks first in resources used when searching for a landscape service provider, but has less impact in the decision process-a result identified in both this study and the ALCA study. The question is: How can contractors continue to nurture and develop the inherent trust transferred from a customer to a potential client? Furthermore, consumers seem to be more willing to trust referrals for services when those services are offered by providers of professional status, as mentioned by Ettenson and Turner (1997) in the differences between professional versus nonprofessional service businesses. The ultimate goal would be for the landscaping industry to transform itself into an industry that requires a "professional" status, so that landscaping providers may also capitalize on its most valued means of acquiring new business. How the industry can accomplish this feat remains an open question and potential topic for further research.

\section{Literature cited}

Associated Landscape Contractors of America. 2004. ALCA's report of landscape industry growth: Trends and buying practices in the consumer market 2004. Associated Landscape Contractors of America, Herndon, VA.

Barton, S., J.R. Booker, C.R. Hall, and S.C. Turner. 1998. Review of customer preference research in the nursery and landscape industry. J. Environ. Hort. 16:118-124.

Beckwith, A. 1996. Small businesses share green commitment. Puget Sound Business J. 20 Dec.:1. 
Behe, B., J. Hardy, S. Barton, J. Brooker, T. Fernandez, C. Hall, J. Hicks, R. Hinson, P. Knight, R. McNiel, T. Page, B. Rowe, C. Safley, and R. Schutzki. 2005. Landscape plant material, size, and design sophistication increase perceived home value. J. Environ. Hort. 23:127-133.

Dillman, D.A. 2000. Mail and Internet surveys: The tailored design method. 2nd ed. Wiley, New York.
Ettenson, R. and K. Turner. 1997. An exploratory investigation of consumer decision making for selected professional and nonprofessional services. J. Services Mktg. 11:91.

Guido, J. 2004. Know your customers. Landscape Mgt. 43:44.

Guido, J. 2005. Your clients define value. Landscape Mgt. 44:42.
Ligos, M. 2001. 2001 survey of buying power and media markets. Sales and marketing management. Bill Publication, New York.

U.S. Census Bureau. 2005. Census 2000 special reports, CENSR-27. Residential finance survey. 13 Mar. 2006. <www. census.gov/prod/2005pubs/censr27.pdf>. 